\title{
GROWTH, STRUCTURAL CHANGE AND PLANTATION TREE CROPS: THE CASE OF RUBBER
}

\section{Colin Barlow}

Department of Economics, Research School of Pacific and Asian Studies, Australian National University, Canberra, ACT, 0200, Australia.

\begin{abstract}
The effects of advancing economic growth on plantations are classed in five stages, starting with conditions in a backward subsistence economy and ending under circumstances where manufacturing is dominant and planting tree crops no longer economic. Changes in relative resource prices and other factors and consequent adjustments of estates and smallholdings are taken into account, doing this in light of international experiences with such crops. The case of natural rubber is scrutinized in depth, comparing economic effects and responses in chief producing countries. The key elements in plantation adjustments of market conditions, technologies, institutional arrangements, and government interventions are finally addressed, with policies likely to facilitate appropriate modifications being indicated.
\end{abstract}

JEL Classifications: 040, 057

August, 1996 


\title{
GROWTH, STRUCTURAL CHANGE AND PLANTATION TREE CROPS: THE CASE OF RUBBER
}

\author{
COLIN BARLOW \\ Australian National University, Canberra*
}

\section{INTRODUCTION}

This paper considers how traditional labour and land-intensive plantation tree crops ${ }^{1}$ have reacted to general economic development, scrutinizing this from when they were introduced as cash crops in subsistence situations to their probable final demise under conditions of dominant manufacturing. It addresses the case of rubber, examining how estates and smallholdings modified production activities with altering labour, land and capital prices, availability of new technologies, and other transformations including more integrated markets, better infrastructures and broadening economic opportunities.

These opportunities included local rubber goods making, responding to domestic demand and export possibilities.

Plantation tree crops merit special consideration in this regard, being major players on the farming scene. They chiefly involve coconuts, rubber, coffee, oil palm, tea, cocoa and various fruits, which today comprise over 25 per cent of the value of agricultural produce in their main growing region of Southeast Asia (Food and Agriculture Organization, 1995) and a higher share of farm exports. They also raise special economic issues compared to annuals, owing to long gestation periods. Their

Thanks are due to colleagues in the plantation and rubber industries of many countries, who willingly supplied guidance and information.

1 A "plantation tree crop" is understood to be one cultivated systematically in a plantation, as opposed to growing naturally in "native groves". Plantations can be established on family smallholdings of a few hectares, or on commercial estates with hired managers and workforces. The latter were privately owned in the early historical period, but are now often "public estates" under national governments. In China and Viet Nam such public estates are usually called "state farms". 
exposure to structural change has affected several hundred million persons producing them around the world, with great economic and social significance in countries concerned.

The approach of the paper is to first present an analytical framework embodying successive stages of economic growth in relation to plantation crops. The circumstances of rubber around the world, and differing modes of national adjustment in the period from the late nineteenth century to the present, are then addressed. Key elements of adjustment are next selected, being reviewed in various national situations. Broad conclusions are finally presented, and general observations made on processes involved.

\section{ANALYTICAL FRAMEWORK}

Consider for the purpose of this framework an economy with three sectors, agriculture, services and industry including manufacturing. Prior to modern growth and introduction of tree crops there is stage (1) of a backward economy, having a dominant subsistence agriculture based on family farms with miniscule services and industry (Table 1). Land is plentiful and underutilized, while labour engaged in shifting cultivation has a low marginal product. Capital is very scarce. These are typical original circumstances in the humid tropics, which form a necessary growing environment for plantation crops.

Enter now international trade and the opening of markets in stage (2) of economic growth, termed early agricultural transformation. Agriculture remains the chief sector, but now has a commercializing orientation while services and industry are growing. This stage frequently coincides with the onset of colonial government and arrival of estates motivated by profits to cultivate plantation crops. The estates need managers and labourers for their institutional structure, while capital from international markets is required to finance these resources ${ }^{2}$. Estate managements and other entrepreneurs now acquire a plantation tree crop technology ${ }^{3}$, promoting its cultivation geared to world markets.

2 Local farmers engaged in shifting cultivation rarely wanted work on estates in these beginning circumstances (Bauer, 1948), meaning labourers had to be imported from outside. This attitude of 
The tree crop is first planted on estates, but is soon taken up by smallholders. It has the key trait of being easily grown, involving simple planting of seeds under relatively unskilled land and labourintensive husbandry. The world market provides what Myint (1958) terms a "vent" for surplus productive capacity, enabling utilization of spare land and (on smallholdings) underemployed labor to produce a valuable export. The widespread adoption of this simple crop with its cash-earning capacity starts transforming the backward domestic economy, encouraging demand for tradeables comprising locally produced foods and imports of other items. Demand for non-tradeables including various public services also rises, and government provides the latter through taxing the new crop. Yet given that tree growing technology remains unchanged, the crop can only continue extending while land and labour resources remain available. Eventually in the absence of resource-saving techniques, no further advances can be made.

But agriculture rarely contains one tree crop and one local food subsector for long, since once entrepreneurs become active and farmers' perceptions improve other simple technology-based exportoriented cash crops are adopted. Constraints on land and labour appear sooner than under one plantation item, and once these are reached competition between individual crops and estates and smallholdings intensifies. Prices of previously plentiful land, labour and other factors begin rising, and profitable subsectors expand exerting "resource pull" effects on others ${ }^{4}$. Factor prices themselves affect profitability, with this being dependent on resource use configurations dictated by underlying technologies. This is the only stage when plantation agriculture leads the economy, for it is later overtaken by other activities. It is termed that of "getting agriculture moving" by Timmer (1988), who analyses agricultural transformation from a perspective of extracting resources for broad national development.

farmers sprang from objective functions emphasizing "subsistence affluence" and disliking the regimented disease-ridden conditions of estate employment.

3 A technology may be defined as the body of knowledge concerning the production of a particular commodity from the appropriate resources. It is representable by a production function (Figure 1). Unique combinations of resources within the technology are referred to as "techniques".

4 Land prices also rise with increasing populations, while the latter tend to reduce prices of labour. 
Now economic growth enters stage (3) of late agricultural transformation, when industry is gaining momentum and manufacturing growing fast on the back of typically government promoted import substitution. Agriculture starts as the biggest sector, but it is overtaken by manufacturing. A vital initiative in this period is demand by producers for new plantation technologies with resource requirements better matching changed factor prices; these involve rises for land and labour, and falls for management and capital which are easier to access. Such demand entails the induced institutional and technical innovation outlined by Binswanger and Ruttan (1978), motivating governments and other agencies to supply research services and researchers to generate less land and labour-intensive technologies.

The new technologies markedly include varieties of trees yielding greater outputs per hectare of land and person-day, albeit requiring more skill and more capital to buy seeds, fertilizers and other chemicals. Once available they are quickly taken up by estates subject to production cycles ${ }^{5}$; this adoption is facilitated by trained managements, capacities to tap central information sources and direct access to capital markets.

But at this juncture a critical limit appears on further plantation smallholding development, applying as well to other small farm sectors. For the new technology is not adopted by most farmers, who continue using old methods though with greater efficiency consequent on learning-by-doing. The limit basically springs from incomplete markets, where despite progress towards more competition many imperfections remain. Thus knowledge and handling skills pertinent to adopting new technologies have not yet diffused to the farm level, while credit for plantation investments with long gestation periods is not available from private lenders. It is pertinent too that smallholders do not match estate operators in demanding the new techniques. This again reflects indifferent market performance, often exacerbated by exclusion of smallholders and other rural dwellers from democratic political activity ${ }^{6}$.

\footnotetext{
5 Most tree crops have gestation or "immature" periods of at least 3-5 years from initial planting to first harvesting. Certain crops have longer periods than this, and smallholder rubber in Indonesia and Nigeria commonly takes 10 years to come to tapping. The "mature" period during which crop is harvested continues 15-25 years, making a total crop cycle of up to 35 years.

6 Thus especially during the colonial period characteristically accompanying early development of plantation crops, smallholder sectors receive short shrift from colonial regimes (see, for example, Murray, 1980, on French Indochina). In contrast, estate sectors are strongly supported during this
} 
Demand for new technologies to be brought to smallholders does ultimately eventuate, however, with this commonly springing from governments and international agencies in the modified public philosophy following transition from colonialism to independence. There is fresh official concern for broad-based economic development and social welfare, with these being pursued through enhanced rural infrastructures and health and education services well as targetted programs. The latter programs include extension and credit to help planting of higher yielding trees on smallholder plantations, often encouraging widespread adoption. Participating farmers further secure advantages of "latecomers", since new technology originally developed for and used by estates now has greater efficiency in terms of higher output-input ratios and wider menus of techniques. The energized government interventions encourage more integrated and competitive rural markets, with these including better information and lower transport costs.

Meanwhile the downstream manufacturing of plantation crops is encouraged by import substitution policies, beginning with simple domestically consumed items and benefitting from accessible raw material production. The national manufacturing expansions of this stage have resource pull effects on other sectors, however, notably respecting labour. They likewise involve spending effects and enhanced demand for services, with consequently rising prices of non-traded goods again lifting resource charges as well as appreciating exchange rates. Such appreciation may also be caused directly by import substitution, and acts to reduce export prices of tree crop outputs.

Next economic development from the viewpoint of plantations enters stage (4) of an early advanced economy (Table 1), starting when manufacturing becomes much larger than agriculture and moves to an export orientation. This reinforces adverse consequences for tree crops just outlined, with rises in land and labour costs now being accompanied by widening rural-urban wage differentials. The latter often trigger urban migration by younger people in particular, posing long-term adjustment difficulties

time, especially in allocating land. Sometimes lack of smallholder consideration is carried forward after independence, particularly when new regimes have no true democratic structure. 
for family-based farms. The raised exports from manufacturing provoke further appreciations in exchange rates.

The manufacturing growth has positive outcomes for plantations, however, notably by strengthening demand linkages through expanded downstream processing. Its spending effects allow heightened government provisions of rural infrastructures and services, all of which stimulate market integration. These provisions may be further increased owing to greater popular pressures accompanying better communications. The generation of new techniques moves firmly towards less land and labourintensive and more management and capital-intensive innovations, being also induced by manufacturers to improve processing and quality methods for fabricating rubber goods.

The newer production innovations are gradually adopted, assisting moves to less costly resources. There may as well be shifts to less labour-intensive tree or annual crops, with these usually being at the ends of cycles. While such changes are again most evident on estates, they are easier to make on smallholdings whose operators are more sophisticated following investments in human capital. The freshly developed processing systems facilitate manufacturers' utilization of plantation products as components of goods chiefly for export.

Finally, economic development reaches stage (5) of a late advanced economy, where manufacturing is dominant and becoming far larger than agriculture (Table 1). Now resource pull, spending and exchange rate effects are greatly accentuated, completely undermining the economic viability of plantations ${ }^{7}$. Wages and land values are far above levels justifying further investment in traditional tree crops, while many rural labourers are ageing and unable to cope following outmigration of younger cohorts. The spending on food of rising urban dwellers is increasingly on meat, fruits and specialist vegetables, reflecting high income elasticities of demand for such products. Both estate operators and better educated smallholders find producing the latter items more profitable, cultivating them using relatively management and capital intensive and labour-saving techniques; they replace

\footnotetext{
${ }^{7}$ The spending and exchange rate effects may also be of "booming sector" origin, springing from exploitation of natural resources including petroleum. Such developments do not use much labour or land, and do not greatly modify prices of those factors.
} 
traditional plantations with them, albeit still exploiting old trees so long as they earn sufficient returns over direct costs.

Manufacturing by this stage includes sizeable downstream plantation crop processing, exploiting economic advantages of utilizing high quality domestically produced intermediate goods consequent on adopting new techniques. Its consumption of these goods has further positive linkage effects, although lower quality needs are often sourced from other countries at earlier stages of development.

Technology generation and adoption in plantation items now concentrate on intermediate goods processing and final goods manufacturing, with main attention to meeting demand on international markets.

Yet although rural markets are much more integrated, pockets of smallholders persist who do not adjust and earn declining incomes in burgeoning general economies. This especially occurs in countries occupying large and scattered land masses, with associated high communication and transportation costs. Often pockets may be promoted by regulations, including legal restrictions preventing rural dwellers from selling land to those who could operate larger more economic units. These regulations paradoxically remain when most official thrusts are towards deregulaton. Governments with spending power in these tend to view such smallholders as objects of welfare: older individuals are helped with income transfers, while younger people are trained to assist shifts to more remunerative opportunities.

This analytical framework rests on observations of economic behaviour in numerous plantation crop countries at differing stages of economic growth. It broadly portrays evolving reality and cannot precisely fit given national tree crop sectors. Its stages are more clearcut than practical eventuality, where some phenomena begin earlier or persist later than suggested. The framework clearly embraces a complex picture, with positive and negative influences at each stage needing to be scrutinized carefully as economic adjustments are explored. The paper now turns to doing the latter for rubber. 


\section{NATURAL RUBBER AS A PLANTATION CASE}

\section{(a) Overall patterns}

Table 2 shows that almost three quarters of natural rubber in the mid 1990s was produced by Thailand, Indonesia, and Malaysia, with almost half the balance coming from India and China. The history of planting rubber goes back to early this century, and Indonesia and Malaysia originally began producing it in the $1900 \mathrm{~s}^{8}$. Thailand only entered the sector $20-30$ years later, however. India first grew the crop in the 1920s, yet only launched it substantially in the 1960s when China was also beginning its cultivation. Other smaller producing countries including Sri Lanka, Viet Nam, and several West African nations started half a century or more ago, and Brazil was the original native source of the rubber tree. The Philippines became a small producer from the $1950 \mathrm{~s}$.

Malaysia's production declined from the late 1980s, responding to very high land and labour costs accompanying its economic advance. But Thai output was still increasing in the 1990s, reflecting a huge program of replanting with high-yielding trees from the mid 1960s. Indonesia's crop was rising steadily on the back of continuing expansion in planted land area. Indian and Chinese supplies were advancing quickly, following active planting with improved trees. Turnout from other small producing nations was growing a little, albeit subject to climatic and other constraints explored below.

Table 2 denotes that most planted rubber is on smallholdings, and this notably applies to the three big producers and India. All countries nonetheless have estate plantings, while the Ivory Coast and Cameroon as well as China and Viet Nam with their state farms have most rubber areas in this class. The institutional arrangements of production influence development significantly, as suggested in the framework.

\footnotetext{
8 Names of countries have frequently been altered over the years, but in this paper are referred to in 1990s terminology. Thailand was called Siam until 1950, whilst Indonesia was known as the Dutch East Indies until 1945. Myanmar was called Burma until the 1970s. Again, some earlier "Indonesian" developments were actually initiated by Dutch colonials, and the same applies to events in ex-British and ex-French colonies.
} 
Table 3 presents selected economic parameters for main natural rubber producing countries over the last two decades, indicating wide divergences in GNPs per head, rates of growth, shares of agriculture and manufacturing, movements in exchange rates and levels of agricultural wages. At one extreme Malaysia following sustained high growth had the highest GNP per head of $\$ 4,010$ in 1995 , and could with its 33 per cent manufacturing share dwarfing the 14 per cent of agriculture be classed as having reached stage (5) of a late advanced economy. At the other extreme Nigeria and Viet Nam with their GNPs in 1993 of $\$ 300$ and $\$ 219$ were still poor countries which had only recently entered stage (3) of late agricultural transformation. These and other economic variations between countries are reflected in divergent resource prices, as seen in wage rates.

It is finally pertinent that rubber like most commercial tree crops can only be grown economically in a humid tropical belt of up to 1,000 kilometres around the equator. Conditions become less suitable for rubber with outward moves in this belt, since dry seasons become longer. Thus Thailand has a three month dry spell in its north east compared to one month in its southern growing areas, while Yunnan which is north of Thailand additionally experiences cold nights and even periodic frosts. Java is good for rubber in the west, but runs into severe dryness constraints towards the east. Yields are lower and production more costly in such outlying places, making rubber less competitive with alternatives.

\section{(b) Transitions between stages}

The natural rubber countries of Tables 2 and 3 together covered all five stages of the analytical framework, taking a period from the late nineteenth century to the present. The years when countries entered and left stages are noted in Table 1. Detailed backgrounds and references on natural rubber in national situations are given by Barlow, Jayasuriya, and Tan (1994).

The move from stage (1) of a backward economy to stage (2) of early agricultural transformation involving rubber occurred in the late nineteeenth and early twentieth century in Indonesia, Malaysia, 
and Sri Lanka ${ }^{9}$. This was a crucial phase in international economic development, coinciding with the opening of Suez and growing international trade from the western industrial revolution. It conformed with the framework in being aided by extensions of colonialism, offering both political stability and regularized contact with external commerce. It was greatly facilitated by introduction of estate enterprises motivated to access and adopt the new rubber growing technology. While these enterprises secured development capital in Europe and America, colonial regimes backed them in obtaining land, importing labour and constructing roads and other infrastructures required to support large scale rubber cultivation (Allen and Donnithorne, 1954).

The simple technology assisted the move to rubber, following the stage (2) prescription in this respect (Table 1). Although it was applied on estates by relatively skilled managers, these were actually hired to control the large workforces. It basically comprised seeds growing into robust trees with scant maintenance and no fertilizer, and was easily handled by smallholders possessing little knowledge, plentiful land, family labour and some access to new infrastructures. It was observed on rubber estates in all three countries by smallholders, who then in gigantic spread effects adopted the technology themselves.

Similar advances spurred by colonialism and estates occurred over the next two decades in Nigeria and Kerala (Table 1). But transformation in Indo-China in the 1920s and the Ivory Coast and Cameroon in the 1950s hardly proceeded beyond estates, for rubber planting on smallholdings was officially discouraged. Small plantations were sluggish in Thailand from beginning in the 1920s, since there was no colonial power and no estate subsector; they only started spreading after official encouragement in the 1960s (Table 2). Early transformation in the Philippines was not reached until the 1950s, when government encouraged first estate and then smallholding expansions as initiatives for its southern island of Mindanao. Stage (2) was completely missed by China, which used state farms to move directly in 1950 from a backward economy into stage (3) of late agricultural transformation.

9 No changes were abrupt, and other plantation crops in the three countries were actually introduced over half a century from the mid-1800s. Rubber was brought in from 1890 to 1910. A similar comment applies to later transitions defined in Table 1, although a decade rather than 50 years is relevant as leeway in these instances. The specified transition years refer to when large alterations first became evident. 
The first entrants to stage (3) were Indonesia, Malaysia and Sri Lanka. These having started plantations earliest began after the 1930s depression to face substantially rising prices of land and labour in regions concerned. The generation of land and labour-saving but more management and capital-intensive high yield technologies marking this stage was primarily by estates in Indonesia, undertaking this cooperatively in response to their own needs. But in the different colonial philosophies of Malaysia and Sri Lanka most research was by government agencies, albeit benefitting through knowledge transfers from path-breaking Indonesian work ${ }^{10}$. Yet while new techniques were mostly adopted by all three countries' estates as they completed crop cycles, the limit on smallholder adoption suggested in the framework was everywhere evident. This almost universally prevented transitions to higher yielding varieties.

After 2 decades and the end of colonialism in the 1950s, however, the depressed circumstances of rubber smallholders in Malaysia and Sri Lanka changed radically. Newly independent governments greatly enhanced rural infrastructures and services, also using credit and extension to encourage adoption by smallholders of higher-yielding trees; the latter had often been greatly improved in the interim, although modifications to suit rather different small farm conditions were frequently needed.

In Indonesia, on the other hand, little altered until the late 1960s due to political instability, absence of economic growth and consequent government inability to undertake much development. But then official efforts were made to stimulate rubber and other tree crop improvement during years of stability and good economic growth from the 1970s to the present. Although good progress eventually occurred with rural infrastructures and services, targetted efforts were constrained by minor resources ${ }^{11}$ and hampered by poor bureaucratic orientation to change. Most rubber smallholders in Indonesia today accordingly still use the original simple technology of the 1900s, albeit with the greater efficiency

\footnotetext{
10 Indonesian research into improved rubber actually began in the 1900s in the government botanic gardens at Bogor. The first breakthrough into high-yielding clones was made in 1915. But under the "laisser-faire" philosoophy of the then Dutch colonial government, most subsesquent research was undertaken by private estate enterprises.

${ }^{11}$ Average real cumulative investment per smallholder rubber farmer in Indonesia is about one fifth of levels in Malaysia, Sri Lanka, and Thailand, according to estimates made by the author.
} 
already suggested through learning-by-doing. This lack of progress is reflected in persisting low yields (Table 2).

The then small Indian natural rubber sector entered stage (3) in 1940 (Table 1), when government help in improvement was spurred by world war and need to produce rubber for the Anglo-AmericanRussian alliance. Subsequently after independence, government support was motivated by the joint desire to promote rural development and achieve rubber self sufficiency for a goods manufacturing sector serving the huge domestic market. Policies resembling those in Malaysia and Sri Lanka were supplemented by high output prices induced through tariffs and quotas on natural rubber imports, consequently stimulating large growths in output from the 1970s (Table 2). Motivations like those of India attended China's efforts to promote natural rubber when it entered stage (3) from the 1960s. The main vehicles of Chinese improvement were state farms, although independent smallholders also began to participate from the late 1970 s under the production responsibility system. The big local demand for natural rubber in China and India is illustrated in Table 2, showing that by 1995 they were third and fourth only to the United States and Japan as global consumers of the commodity. Their rapid consumption increases likewise meant they had to supplement home production with imports.

Yet the most impressive movement in stage (3) took place in Thailand, beginning as indicated in the 1960s and building on minor areas of rubber smallholdings. The government much improved infrastructures and services ${ }^{12}$, and in institutional spillovers from Malaysia and Sri Lanka established targetted extension and credit arrangements to assist rubber planting. These actions were very effective, transforming the smallholder-based Thai rubber sector from minor player to global leader in less than three decades (Table 2).

All other listed countries apart from Kampuchea moved to late agricultural transformation with rubber in the 1970s (Table 1), but excepting the Philippines shifts to new techniques were chiefly confined to estates. In Viet Nam as in China efforts were channelled through state farms, albeit with

\footnotetext{
12 These efforts were also connected with attempts to eliminate widespread communist insurgency in
} southern Thailand. 
small moves to encourage smallholders from the 1980s. In Nigeria even stage (3) transformations on estates were muted, since workers were drawn from all rural activities by massive urban projects financed by the oil boom revenues of government. Although the Ivory Coast and Cameroon tried from the 1980s to include smallholders in "nucleus estates" giving technical help and other services to surrounding farmers, these had limited impact since managers tried to maximize benefits to core operations. It is interesting, indeed, that nucleus estates were employed in Indonesia with similar disappointing outcomes. In the Philippines, however, smallholdings benefitted from estate spread effects as well as direct government help. All countries coming to stage (3) at later times gained through technical spillovers from earlier entrants, and notably from larger rubber nations sustaining economies in research. Yet onward adaptation of techniques was also usually needed, and its absence in Indonesia and West Africa acted to brake adoption.

The postulated economic growth effects on resource prices were universally evident during early and late agricultural transformation, although sometimes mitigated by market imperfections and remoteness from development centres; the latter especially occurred in countries where government failed to improve market integration and enhance competition. Rural wages were placed under further upward pressures owing to import-substituting policies during late transformation, and this notably occurred where rubber was grown near industrializing centres; it was true, for example, of peninsular Malaysia in the 1960s and Hainan-Guangdong in the 1990s. Although import substitution tended to appreciate exchange rates in the mode of the framework, most countries except Thailand, Malaysia and West African nations engineered large depreciations against the U.S. dollar in which rubber is traded (Table 3). These depreciations from the 1970s reacted to freer world financial markets and followed earlier overvaluations, usefully raising domestic prices of rubber and other export items.

Given the new techniques, estates in stage (3) moved strongly in altered price configurations to plant rubber, though sometimes shifting to less-labour intensive crops like oil palm, cocoa and fruit trees. Smallholders getting effective official help mainly established rubber, which for them was the 
most suitable crop ${ }^{13}$. These investments were reflected in large rubber output rises from the 1950 s to the 1990s in Thailand, Malaysia, India, China and other countries growing improved trees(Table 2).

Desires to invest in rubber planting noticeably diminished with the entry to early advanced economy, however, beginning with Malaysia in 1970 and Thailand in 1985 (Table 1). Now rubber workers had many new opportunities including jobs in urban areas; these were actively taken up by the Malaysian younger generation, causing dramatic shifts of population to towns from the mid 1970s. The changes acted to enhance rural wages, although this was countered through mounting and often "illegal" entry of migrant labourers from Indonesia and elsewhere. Modes of production from existing trees shifted towards labour-saving methods, drawing on techniques now generated by researchers. Similar trends occurred in Thailand, where labour shortages were counteracted by migrants from depressed national areas and Myanmar. Official Thai schemes now allowed producers to interplant rubber with fruit trees, thus hedging against possible declines in profitability. They further endeavoured to stimulate enhanced rubber planting in the north-east of the country. That seemed unlikely to be successful, however, owing to low profit expectations under poor climatic conditions and existence of better alternatives.

Shifts to export-oriented manufacturing occurred in both countries in stage (4), and helped generate the wage pressures outlined. They were encouraged by new emphases on economic deregulation, leading to even more open economies. Such manufacturing followed the framework in including rubber goods sectors favouring natural-rubber intensive products; these especially comprised heavy duty tyres and "latex" items like surgical gloves and condoms, being supported by new techniques coming from research institutes. This build-up was partly achieved through joint ventures serving to establish an expertise base, meaning Malaysia was now becoming a global specialist in products concerned. The Malaysian and Thai manufacturing growth from the 1980s caused slight currency appreciations, accordingly penalizing traditional plantation and other export crop producers.

13 But the distribution between producers and consumers of benefits from these improvements depended on relative price elasticities of supply and demand for rubber. Under the usual inelastic rubber supply and elastic demand, perhaps half the benefits accrued to consumers. 
Finally, only Malaysia amongst natural rubber countries entered stage (5) of a late advanced economy, doing this in the mid-1980s (Table 1). Further rubber planting was not economic with very high wages (Table 3) and land prices, but estates continued to exploit old rubber trees employing mainly foreign migrants. At the ends of crop cycles they partly replanted with less labour-intensive crops, utilizing other land for housing or industry. Smallholders too went on tapping rubber with hired migrants, although their higher price elasticities of supply meant outputs declined greatly during the low output prices of the early $1990 \mathrm{~s}^{14}$. The family ageing factor suggested in the framework also operated, and taken with restricted land transfers meant old smallholding rubber parcels were often abandoned rather than sold, amalgamated and planted to new more crops. Government support for older Malaysian rubber workers was increasingly seen as welfare, albeit accompanied by the reorganizing production in block development schemes ${ }^{15}$.

The growth of export-oriented rubber goods manufacturing continued apace in stage (5), and Malaysia with its specialization had become the fifth biggest global consumer of natural rubber by the mid 1990s (Table 2). It had through its manufacturing technology generation become the source of certain new processing techniques now licensed to other ventures around the world. As suggested in the framework, it sourced much of its lower-quality rubber from other less developed sectors, notably Vietnam and Nigeria.

The impacts on rubber plantations of changing resource prices in stages (3), (4) and (5) are shown in Table 4, which presents estimated costs of production per kg. using improved techniques. The budgets are judged realistic, being based on studies of national production sectors. The wage of $\$ 2$ per day and land price of $\$ 250$ per hectare under late agricultural transformation represent the current position of countries like Indonesia and the Philippines, while the much higher figures of $\$ 10$ and $\$ 12,000$ under

14 These were the last straw for many farmers, who were thereby encouraged to permanently leave their lands.

15 These "mini-estate" and other schemes were managed by the rural development bureaucracy, and while technically efficient were quite uneconomic. They entailed heavy subsidies and employment of migrant workers to produce rubber, proceeds from which were paid to original smallholder owners who were now shareholders. They resembled state-sponsored agricultural schemes in Korea, Taiwan and other countries well into the advanced economy stage, being further justified by support from politically powerful groups. 
late advanced economy are levels reached by Malaysia. Table 4 takes into account improvements in labour use efficiency and lowerings of transport and forwarding charges during the transition, as well as substitutions of material inputs like fertilizers and yield stimulants for labour.

Taking the border price range of 75-150 cts per kg obtaining in 1990-1995, only producers in late agricultural transformation consistently earn profits over grand total estimated costs. Those in early advanced economy earn profit at the high end of the price range, while those in late advanced economy always incur a loss. Circumstances look better when variable production costs alone are considered, which is the appropriate short-term outlook; then even producers in late advanced economy earn some profit at higher price levels. These comparisons illustrate disincentives to rubber growers from labour and land price rises.

Actual responses of Malaysian rubber estates and smallholdings to changing factor prices in stages (2) to (5) are presented in Table 5, which details altering shares of land, labour, management and capital as well as costs of these items and other information at intervals over 70 years. Average prices of land and labour are given, although opportunity costs of smallholder resources were often lower than quoted market rates. Unfortunately comparisons are not controlled, since surveys underlying the data were conducted for varying purposes. Yet they are still thought to portray evolving circumstances quite well.

Table 5 denotes large shifts in factor shares, with land on estates climbing from minor roles in initial development and production phases in 1922 to almost 50 per cent in 1995. Labour, in contrast, tended to decline in share over the period, where its substitution by capital inputs like heavy land clearing machines much reduced its part in initial development; thus the huge absolute labour inputs in this phase in 1922 had fallen to less than one sixth by 1995 . These and other changes such as the large drop over recent decades in capital inputs in field production on estates and smallholdings also reflected increased technical efficiency through learning-by-doing, It is interesting as well to note big estate yield increases up to the 1960s, with little advance thereafter. These suggest diminishing returns in 
yield improvement, resembling the performance of most crops touched by the "green revolution" in Asia and elsewhere.

(c) Key elements in adjustment

Market conditions along with technologies, institutional arrangements and government interventions are each seen as crucially influencing rubber sector adjustments to economic growth. These four elements are now reviewed in turn.

The differing market conditions facing estates and smallholdings growing rubber and other plantation crops are well portrayed by what Myint (1992) terms "organizational dualism"; this entails the co-existence on the one hand of a fully organized economy with "free flowing" linkages, and on the other hand of an "underdeveloped economy". The output, capital and labour markets of the latter are incomplete, having high transport, information and other transaction costs. They are also segmented, with differing prices facing participants in each portion. The underdeveloped economy likewise has a poorly funded bureaucracy, making high charges for inferior services. The two market portions are still closely connected, however, and far from the entire separation postulated by Boeke (1966).

Estates fall in the fully organized portion of this paradigm, although it is notable that their large size gives them economies in accessing markets for outputs, capital,information and other inputs as well as supplying infrastructures and services; these economies mean they are not subject to markets of surrounding rural areas. Smallholdings are in the other portion of the paradigm, for they do not possess such economies and have to depend on the latter. Such differing market conditions crucially affect adjustments through technology adoption and other means.

Yet incomplete markets did not prevent smallholdings from adopting the early simple and almost exclusively land and labour-using rubber-growing technology, given it became available through international linkages of the estates. The slight necessary information flowed easily to individual 
farmers, whose acceptance followed the usual mechanism of starting with progressive individuals and spreading to others in a bandwaggon effect. Little skill was entailed in planting or subsequent harvesting, and this together with high anticipated profitability explained the rapid diffusion of first smallholding plantations ${ }^{16}$. It should also be noted as a further positive aspect that smallholdings in most countries had good access to output markets through ubiquitous local traders, who in Southeast Asia were largely Chinese. These traders helped too in distributing seed obtained from neighbouring estates.

But when it came to new skill and capital-intensive high-yielding rubber technologies rapidly taken up by estates ${ }^{17}$ in stage (3) of late agricultural transformation, acceptance by smallholders in all countries was virtually non-existent. Information flowing to farmers about complex methods and related activities was deficient, while long-term credit for sizeable purchased inputs was not available from trader-lenders ignorant about a risky venture with deferred returns. Incentives were further reduced by high transportation charges, which raised costs of purchased items. Yet as mentioned above incomplete markets often meant prices of land and labour remained depressed, enabling old techniques to stay profitable; this was a positive short-term factor, but further delayed adoption of new technology.

While these barriers to adoption were dealt with by targetted government interventions in Malaysia, India, Thailand and other countries, they ultimately began to be overcome even in contexts without assistance. Lagged technology spread effects from estates and other centres to smallholdings eventually became evident, although admittedly facilitated by other official infrastructure and services which reduced transport costs and improved information. Such effects were further encouraged by enhanced linkages and competition attending overall growth of the economy.

16 Acceptance of this simple technology and its equivalent for other tree crops was eased by the fact that they fitted concurrent swidden systems, whereby land was cleared and planted with subsistence items. Now the seeds of the new technology were planted alongside subsistence items, involving minimal extra costs together with anticipations of substantial extra returns.

17 The generation of technologies themselves usually required government intervention even with estates, and was justified by the public goods argument. The only exception was in the Dutch East Indies, where estates were constrained by government to mount two big cooperative research centres. 
In Indonesia in the 1980s and 1990s, for example, ex-estate workers and their children began 50-60 years after improved rubber and other plantation crops were introduced on estates to plant these in lands they had acquired around estate borders. They also set up private nurseries from which higher yielding stock was sold to the huge majority of smallholders still using 1900s technology (Barlow, $1995)^{18}$. Government road and education programs were now having real impact despite little targetted intervention, and steady national economic expansion (Table 3) had further positive influence. Yet these delayed and usually poorly executed adjustments in Indonesia were still small in effect, highlighting the advantages of supervised interventions in other countries. By stages (4) and (5) of advanced economy, on the other hand, rural markets were far more integrated and competitive. Provided there were no constraints such as those on land in Malaysia, conversions to newer crops including fruit trees took place without official assistance.

The role of technologies as another key element in adjustment is helpfully explored through considering underlying innovations and their use of resources. Viewing rubber and other plantation technologies as isoquants utilizing labour and capital, robust trees introduced in stage (2) of early agricultural transformation are represented in Figure 1 as $\mathrm{Y}_{0} \mathrm{Y}_{0}$; this has wide possible substitution between resources, permitting estates with cheap capital to operate at $\mathrm{E}_{1}$ and smallholdings to work at $S_{1}$. These circumstances explain how different production systems used the same early technology. But the new technology introduced during stage (3) (Table 1) is featured as $Y_{1} Y_{1}$, allowing far less substitution between factors and needing proportionately more capital; such a portayal assists in explaining why adoption was hard for smallholders. Subsequent production research continuing into stage (4) of early advanced economy then generated a menu of technologies like $Y_{2} Y_{2}$ or $Y_{3} Y_{3}$, making possible choice of techniques more suitable for given smallholding (and estate) conditions. This later research thrust importantly facilitated adjustment.

It is useful to distinguish embodied and disembodied technologies, where the former are "built into" long term production inputs such as trees or processing machines. The latter are not so tied, however,

18 Unfortunately the quality of high-yielding materials was poor, and far below that distributed through government operated schemes in other countries. Smallholders with their inferior information did not recognize this, however. 
comprising shorter term items like fertilizers, weedicides, yield stimulants and modified factory routines. Embodied technologies have impacts over long periods, but disembodied technologies exercise quicker effects; they may indeed be applied with embodied technologies at particular times, enabling factor substitution as well as yield and quality adjustments. Using rubber yield stimulants with technology $\mathrm{Y}_{2} \mathrm{Y}_{2}$, for example, extends the overall disembodied-embodied isoquant along the dotted line in the direction of capital (Figure 1), allowing reduced labour use to secure a given output. This stimulant approach was profitably employed on remaining estate rubber areas during advanced economy stages in Malaysia.

A major economic aspect of technology use is learning-by-doing, which was measured with Indonesian rubber smallholders. Thus farm records over 70 years with the first simple labour-intensive rubber technology demonstrated sizeable rises in technical efficiency, giving yield advances of 30 per cent associated with large reductions in labour use (Barlow, Jayasuriya and Tan, 1994). If $\mathrm{Y}_{0} \mathrm{Y}_{0}$ in Figure 1 is now taken as a frontier production function indicating best possible performance, these rises involved a move like that from $S_{0}$ to $S_{1}$ for smallholdings or $E_{0}$ to $E_{1}$ for estates. Improved allocative efficiency would also have occurred, but was not quantified. While bigger learning gains were certainly secured with new technologies, these were hard to assess owing to the wide range of inputs involved. Such gains were connected with many government-sponsored plantation extension programs, and an important aspect facilitating adjustment.

Most transferred technologies performed indifferently in new environments, with outcomes represented by the inferior position of isoquant $\mathrm{Y}_{4} \mathrm{Y}_{4}$ in Figure 1. Modifying research was needed to move isoquants to higher yielding sites like $\mathrm{Y}_{1} \mathrm{Y}_{1}, \mathrm{Y}_{2} \mathrm{Y}_{2}$, and $\mathrm{Y}_{3} \mathrm{Y}_{3}$, and usually concerned both embodied and disembodied technologies. Hence Chinese researchers cleverly improved trees imported from other rubber-growing regions, and also devised cultivation methods to help cope with the periodically windy, cold and dry conditions in Yunnan. They consequently made it possible to secure yields as high as those in more favoured rubber regions (Huang and Pan, 1992). Similar adjustments were made elsewhere, being crucial to economic viability of sectors concerned. 
The respective institutional arrangements of estates and smallholdings manifestly influenced the economic performance of plantations at all stages of adjustment. The two sets of arrangements are strikingly different, relating to divergent socio-economic contexts and the dualism previously addressed.

Estates sustained marked scale economies in accessing inputs and outputs, as well as in initial development, processing and output handling. Thus they secured cheap capital and information, adjusted quickly to new techniques, and had low costs per unit in most operations. They likewise obtained vertical integration economies through being in conglomerates with central selling organizations, giving good access to information about technologies and buyers' requirements. They were insulated from incomplete markets facing smallholders, while at least during colonialism their size gave them political influence on government. The latter assisted early land acquisitions, with areas frequently being level, fertile and close to points of export; such good siting still compares today with hilly and remote peripheries often occupied by smallholdings. Estate arrangements also had disadvantages, however, especially when integration under post-independence public control incurred diseconomies from bureaucracies and politicians.

Smallholdings as such had none of the estate merits, although their family basis conferred low interpersonal monitoring charges. They also gained through multi-product orientation, where given plantation crops rarely occupied more than half their output value; this hedged against downward price fluctuations, helping explain characteristically high price elasticities of supply. Smallholdings had further to be viewed together with their purchasing network of traders, who ordinarily offered competitive output markets with significant scale and vertical integration economies. These output markets were still subject to high transport costs, however, while input markets for information, capital, new technologies and associated inputs were all incomplete causing indifferent performances described.

A pertinent question is why smallholding plantations have survived and in fact expanded beside estates with their economic superiority in most spheres. One major explanation lies in low opportunity costs of resources, where especially up to stage (4) family members often worked for returns under 
market wages. This applied even more to land, which frequently had little value owing to legal and other restrictions on transfers outside narrowly defined groups or clans. Remoteness of smallholdings likewise protected immediate economic viability, reinforcing market imperfections and preserving low land and labour costs. The popular dislike of estates due to associations first with colonialism and later with modern elites further assisted small units, helping to limit estates to areas alienated during early development or previously unoccupied lands.

Another factor strongly bolstering smallholdings in some countries were targetted government interventions. These by overcoming incomplete markets and enabling adoption of better trees brought farmers to positions of earning good incomes and later adjusting autonomously to even newer opportunities. Finally, the public control of many estate sectors following independence reduced economic performances, accordingly bolstering smallholdings. Although this control included major subsidies and political support, it visibly undermined economic operation and occasioned moves to reprivatization in the 1990s.

The institutional arrangements of targetted government programs for smallholdings have likewise been critical to success, and broadly fall into two categories. One is "dispersed", in the sense of arrangements making improved trees, credit and training available to all individual farmers wishing to take part. It is well illustrated by rubber extension in Thailand, which ingeniously and effectively meets farmers' planting needs. The other category is "focussed", concentrating on selected cultivator groups which receive much greater financial support together with management assistance. It is typified by nucleus estate projects, as well as by comprehensive land development schemes like those of the Federal Land Development Authority in Malaysia. These focussed schemes attempt to capture economic advantages of scale and integration, and also frequently include welfare purposes in settling landless people. The land schemes have often proved successful, although nucleus programs have mainly failed.

It seems from international experience with tree crop smallholders and other small farmers that dispersed strategies are more economically effective than focussed approaches, not least because they 
distribute benefits more widely (Tomich, Johnston and Kilby, 1995): immediate returns to intervention are higher, while more significant spread effects are exercised in surrounding communities. But a mix of the categories is usually implemented owing to welfare and political considerations..

Lastly, government interventions at both micro and macro levels have crucially affected adjustment of plantations, being accordingly fundamental policy considerations.

Micro interventions influencing plantations comprise roads, other infrastructures and general education and health services on the hand, and targetted programs including credit, extension and research on the other. All may be seen as public goods of collective consumption, profitable for society as a whole but either not supplied or only produced at sub-optimal levels by private firms. Their furnishing by government has vitally aided smallholdings in overcoming incomplete markets and defective bureaucracies, with this successfully occurring in many national contexts. But sometimes targetted programs in particular were ineffective owing to inadequate funds, poor planning or persisting deficiencies in the official apparatus. These were all difficulties with rubber in Indonesia, although infrastructure and service provisions in that country were generally appropriate.

It is pertinent to question whether private sector agents could have undertaken some adjustments more efficiently. Such agents clearly did little to improve smallholder input markets of all countries during stage (3) of late agricultural transformation, although sluggish private adaptations commenced belatedly in Indonesia. Calculations by the author weighing benefits and costs of official Malaysian and Thai rubber improvement schemes denote highly positive rates of return, especially for the latter ${ }^{19}$. They also indicate big gains compared to situations in countries where public targetted programs were minor. It does indeed seem incontrovertible that government micro interventions were hugely helpful to adjustment, although contracting private agencies for certain tasks might have raised effectiveness in some instances.

19 Calculations were made separately for research and planting support programs, taking into account flows of costs and benefits over 30-40 years. While all costs were accounted for, only "immediate" benefits to producers in terms of estimated values of higher yields were considered, and substantial secondary gains flowing from farmer training and improved market integration were excluded. 
Macro interventions affecting tree crops include exchange rate, trade and price administration measures, all of which may substantially influence economic performance. Assessments here are more mixed, where overvalued exchange rates in the 1950s and 1960s disadvantaged rubber and traditional sectors in all countries except Malaysia and Thailand. Again, the import substitution policies of stage (3) put upward pressures on rates as well as resource prices with few apparent gains. Indeed, the Indian and Chinese output price supports and input subsidies greatly boosting rubber outputs led to expensive crops of doubtful economic merit. The cold region rubber production of Yunnan, for example, is unlikely to be profitable at world price levels. While these Indian and Chinese policies were politically justified by self-sufficiency, they may not be maintained under globally reducing protection combined with availability of cheaper imported rubbers. In such circumstances smallholders and others face painful adjustments, whose costs could offset benefits received to date.

Within this scenario the much more open Thai and Malaysian regimes stand out as positively assisting adjustments in rubber and other sectors. These regimes helped promote continuing high GDP growth in recent decades (Table 2), and despite constraints favoured local prices reflecting global levels and impelling pertinent economic change. The strong export orientation of manufacturing sectors facilitated downstream developments of rubber processing, realizing substantial comparative advantages in fabricating certain rubber goods.

\section{CONCLUSIONS}

The five-stage analytical framework of this paper is thought to assist appreciation of how economic growth affects plantation growers, and of how to achieve appropriate adjustments. The detailed scrutinies of natural rubber highlight pressures and responses involved, as well as policies likely to assist producers in effective responses. 
The key element in adjustment of market conditions and seriously incomplete input trade is seen as a large constraint on smallholdings, while the further element of technology entailing generation and adoption of suitable cost-reducing and quality-improving techniques appears vital to pertinent economic changes. The element of institutional arrangements of estates and smallholdings manifestly influences economic performance, where the formers' size and vertical linkages confer big advantages. But smallholdings have the merit of access to competitive output markets, providing substantial economies in handling and processing their crops.

The final key element in adjustment of government interventions has major policy implications, warranting special concluding emphasis. Micro level help in overcoming difficulties of smallholding input markets seems very necessary and economically advantageous. One aspect of this is providing general infrastructures and services, and the other aspect mounting targetted programs for particular crops. The latter programs seem best organized on a model of dispersed assistance to individual smallholders, giving superior returns to investments. Further micro support is critical in generating technologies for estates and smallholdings, but this is the only need for the former which otherwise seem able to accomodate change.

Not all micro interventions have been successful, however, and some targetted programs have failed. Here lessons can be learned from successful initiatives, notably including dispersed assistance schemes in Thailand and Malaysia. Provisions of infrastructures and services have been more broadly effective, although these too need to meet special needs of smallholdings.

Government macro level interventions have often obstructed adjustment, on the other hand, and the paper highlights gains from open trading policies compared to protective approaches. Thai and Malaysian policies once more emerge as superior in this respect, with economic pricing of inputs and outputs having been helpful in stimulating appropriate changes. It is no coincidence that these countries have developed furthest, having both now entered the stages of advanced economy. 
Excepting Malaysia, plantations in all countries have still to traverse all five stages of the analytical framework, and most have only reached late agricultural transformation. The foregoing analyses indicate relevant adjustment paths for what in most instances remain highly significant sectors of national economies.

\section{REFERENCES}

Allen, G.C. and A. Donnithorne, Western Enterprise in Indonesia and Malaya. A Study in Economic Development (London: George Allen and Unwin, Ltd., 1954)

Barlow, C, "The Market for Tree Crop Technology: a Sumatran Case", Economics Division Working Paper 95/3 (Canberra: Research School of Pacific and Asian Studies, Australian National University, 1995).

Barlow, C., S.K. Jayasuriya, and C.S. Tan, The World Rubber Industry (London and New York: Routledge, 1994).

Bauer. P.T., The Rubber Industry. A Study in Competition and Monopoly (London: Longman, Green and Co., Ltd., 1948).

Binswanger, H.P.and V.W. Ruttan, Induced Innovation. Technology, Institutions and Development (Baltimore: The Johns Hopkins University Press, 1978).

Huang, Z.D. and Y.Q. Pan, "Rubber Cultivation under Climatic Stresses in China". Chapter 10 in Sethuraj, M.R. and N.M. Mathew (eds), Natural Rubber: Biology, Cultivation and Technology (Amsterdam: Elsevier, 1992)

International Rubber Study Group, Rubber Statistical Bulletin (Monthly), (London: IRSG, 1946-96).

Murray, M.J., The Development of Capitalism in Colonial Indochina (1870-1940) (Berkeley:

University of California Press, 1980).

Myint, H., "An interpretation of economic backwardness", Oxford Economic Papers, 6 (1954), pp 132162. 
Myint, H., “Organizational Dualism and Economic Development”, Asian Development Review, (1992), pp 24-42.

Timmer, C.P., "The Agricultural Transformation", in Chenery, H. and Srinivasan T.N. (Eds), Handbook of Development Economics, Vol 1 (Amsterdam: North Holland, 1988), pp 276-331.

Tomich, T.P., P. Kilby, and B.F. Johnston, Transforming Traditional Economies. Opportunities seized, Opportunities missed (Ithaca: Cornell University Press, 1995).

World Bank, World Tables, 1996 (Baltimore: Johns Hopkins University Press, 1996). 


\begin{tabular}{|c|c|c|}
\hline Stages & Characteristics $^{\mathbf{a}}$ & $\begin{array}{c}\text { National } \\
\text { positions } \\
\text { with rubber }\end{array}$ \\
\hline
\end{tabular}

(1) Backward economy

(subsistence agriculture, $\underline{\text { no }}$ plantation crops)
- Predominant subsistence agriculture, minuscule services and industry.

- Little trade and fragmented rural markets.

- Plentiful and underutilized land, labour with low marginal product, very scarce capital.

- Historically established shifting cultivation technology on family smallholdings.

- Minimal government ${ }^{\mathrm{d}}$.
Thailand to 1920

Indonesia (outer islands) to $1870^{\mathrm{c}}$

Malaysia to $1870^{\mathrm{c}}$

India (Kerala) to 1920

China (Yunnan \& Hainan)

to 1960

Sri Lanka to $1870^{\mathrm{c}}$

Nigeria (southern area) to $1910^{\mathrm{e}}$

Viet Nam to 1920

Philippines (Mindanao) to 1950

Ivory Coast to 1950

Cameroon to 1950

Kampuchea to 1920
(2) Early agricultural transformation (simple plantation crops technology)
- Commercializing agriculture the dominant sector, with estates and smallholdings both involved in plantation crop cultivation. Small but growing services and industry.

- International trade ${ }^{\mathrm{f}}$ and rural market development commencing.

- Land and labour becoming scarce and prices rising, capital becoming more available.

- Rapid adoption of simple labour-intensive tree crop technologies, first on estates and then on smallholdings.

- Central government begins levying taxes and providing small services.
Thailand, 1920-60

Indonesia, 1900-30 ${ }^{\mathrm{c}}$

Malaysia, $1900-30^{\mathrm{c}}$

India, 1920-40

China, missed out

Sri Lanka, 1900-1930

Nigeria, 1910-70

Viet Nam, 1920-40

Philippines, 1950-70

Ivory Coast, 1950-70

Cameroon, 1950-70

Kampuchea, 1920-80
(3) Late agricultural transformation (new plantation crops technology)
- Agriculture remains one of bigger sectors, but services increasing and manufacturing based on import-substitution passes agriculture towards end of period.

- Rural market development progressing, especially with government interventions. But many imperfections persist.

- Land and labour prices rising; capital, management and transport prices falling.

- Generation of new land and labour-saving but more
Thailand, 1960-85 Indonesia, 1930-present Malaysia, 1930-1970 India, 1940-present China, 1960-present Sri Lanka, 1930-present Nigeria, 1970-present Viet Nam, 1970-present Philippines, 1970-present Ivory Coast, 1970-present 
capital and management-intensive high-yielding tree crop technologies. Adoption first by estates and much later by smallholdings.

- Central government gradually widening supporting role, and following end of colonialism providing widespread rural infrastructures and services. Government also promoting import-substituting manufacturing.
Cameroon, 1970-present

Kampuchea, 1980-present 
Table 1 (cont'd)

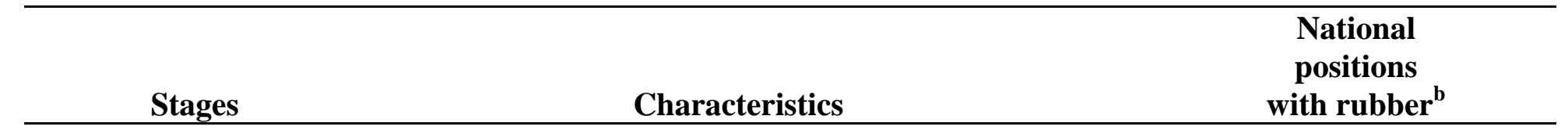

(4) Early advanced economy (plantation crops becoming less profitable)
- Manufacturing becomes much larger than agriculture, being increasingly export-oriented and including downstream plantation crop processing into final goods.

- Rural market much better integrated and competitive, pockets of imperfection persist.

- Resource price trends of (3) continuing, but land and labour price rises accelerating and rural-urban wage differentials widening. Consequent labour migration to towns.

- Tree crop technology generation and adoption continuing in directions under (3), with concomitant widening of available techniques to assist adjustment to different circumstances. Shifting towards generation and adoption (by plantation crop processors) of quality-improving techniques needed by plantation crop goods subsector.

- Government going on with provisions of rural infrastructures and services under (3). Previous regulations in trade being gradually removed.
Thailand, 1985-present

Malaysia, 1970-85
(5) Late advanced economy (plantation crops not profitable)
- Manufacturing now predominant, being two or more times bigger than agriculture and including significant plantation crop processing into final goods. Also importation of natural rubber from other countries to supply this goods industry.

- Rural market as for (4), albeit superior to it in integration and competition.

- Resource price and exchange rate trends of (4) persisting. Traditional plantation crop production is uneconomic, but existing trees still being exploited in 'sunset' setting.

- Tree crop technology generation and adoption chiefly concentrating on quality-improving techniques for goods subsector.

- Government continuing as under (4). Remaining plantation crop support measures largely welfare for older generations.

Malaysia, 1985-present 
Notes: a. Divided in each stage between the 'main' characteristic in terms of sectoral balance (in italics) and 'associated' characteristics.

b. Which came in after the Backward Economy (stage 1).

c. Coconut, coffee and cocoa from 1870, rubber first planted in 1900.

d. Traditional government comprising little local kingdoms which may nonetheless collect tax. 'Central government' from (stage 2) often entails an invading colonial regime, although by the end of (stage 3) it is usually of 'independent' local origin. The modern nation states then involved have varying degrees of devolution at local level.

e. Wild Funtumia rubber exploitation began in the late nineteenth century, and accounts for early Nigerian output (Table 2).

f. This feature persists for remaining stages, becoming increasingly important. 
32

Table 2. World natural rubber production

\begin{tabular}{|c|c|c|c|c|c|c|c|}
\hline & Thailand & Indonesia & Malaysia & India & China & Sri Lanka & Viet $\mathrm{Nam}^{\mathrm{a}}$ \\
\hline \multicolumn{8}{|l|}{ Production ('000t) } \\
\hline - 1910 & - & $3(3)^{b}$ & $6(6)$ & - & - & $2(2)$ & - \\
\hline - 1930 & $4(1)$ & $245(29)$ & $467(56)$ & $9(1)$ & - & $77(9)$ & $11(1)$ \\
\hline - 1950 & $114(6)$ & 707 (37) & $761(40)$ & $16(1)$ & - & $116(6)$ & $92(5)$ \\
\hline - 1970 & $287(9)$ & $815(26)$ & $1,269(40)$ & $90(3)$ & $46(1)$ & $159(5)$ & $28(1)$ \\
\hline - 1990 & $\begin{array}{r}1,271 \\
(25)\end{array}$ & $\begin{array}{r}1,262 \\
(25)\end{array}$ & $1,291(25)$ & $324(6)$ & $264(5)$ & $113(2)$ & $103(2)$ \\
\hline - 1995 & $\begin{array}{r}1,786 \\
(31)\end{array}$ & $\begin{array}{r}1,420 \\
(24)\end{array}$ & $1,085(19)$ & $500(9)$ & $360(2)$ & $103(2)$ & $95(2)$ \\
\hline Area, 1990 ('000 ha) & $\begin{array}{l}1,844 \\
{[95]^{\mathrm{c}}}\end{array}$ & $\begin{array}{r}3,155 \\
{[83]}\end{array}$ & $1,837[81]$ & $451[83]$ & 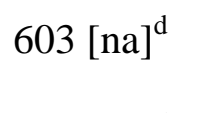 & $199[33]$ & $250[\mathrm{na}]$ \\
\hline $\begin{array}{l}\text { High-yielding trees, } 1995 \\
(\%)^{\mathrm{e}} \\
\text { Yield, } 1990\end{array}$ & 52 & 17 & 95 & 92 & $100^{f}$ & 75 & 15 \\
\hline - $\quad(\mathrm{kg} / \mathrm{mature} \mathrm{ha)}$ & 847 & 677 & 800 & 1,057 & na & 772 & na \\
\hline - $\quad$ (kg/planted ha) & 689 & 400 & 599 & 718 & 438 & 568 & 352 \\
\hline \multirow{2}{*}{$\begin{array}{l}\text { Consumption, } 1995 \\
\left({ }^{\prime} 000 \mathrm{t}\right)\end{array}$} & 150 & 133 & 327 & 516 & 732 & 36 & 30 \\
\hline & Nigeria $^{g}$ & $\begin{array}{l}\text { Ivory } \\
\text { Coast }\end{array}$ & Philippines & Cameroon & Kampuchea & Others $^{h}$ & World \\
\hline \multicolumn{8}{|l|}{ Production ('000t) } \\
\hline - 1910 & $14(14)^{b}$ & $\mathrm{~g}$ & - & $\mathrm{g}$ & - & $70(65)$ & 98 \\
\hline - 1930 & $5(1)$ & g & - & $\mathrm{g}$ & $\mathrm{a}$ & $20(2)$ & 838 \\
\hline - 1950 & $56(3)$ & $\mathrm{g}$ & $1(-)$ & $\mathrm{g}$ & $\mathrm{a}$ & $27(1)$ & 1,890 \\
\hline - 1970 & $65(2)$ & $11(-)$ & $20(1)$ & $12(-)$ & $3(-)$ & $172(5)$ & 3,140 \\
\hline - 1990 & $152(3)$ & $69(1)$ & $61(1)$ & $38(1)$ & $35(1)$ & $136(3)$ & 5,120 \\
\hline - 1995 & $93(2)$ & 77 (1) & $60(1)$ & $55(1)$ & 44() & $142(2)$ & 5,820 \\
\hline Area, 1990 ('000 ha) & $\begin{array}{r}247 \\
{[81]^{\mathrm{c}}}\end{array}$ & $68[29]^{a}$ & $88[75]^{\mathrm{i}}$ & $41[5]^{i}$ & 19 [na] & 283 [na] & $9,085^{\mathrm{e}}$ \\
\hline $\begin{array}{l}\text { High-yielding trees, } 1995 \\
(\%)^{\mathrm{e}}\end{array}$ & 10 & 90 & 30 & 70 & 10 & na & na \\
\hline Yield, 1990 & & & & & & & \\
\hline - $\quad$ (kg/mature ha) & na & 1,712 & 841 & na & na & na & na \\
\hline - $\quad(\mathrm{kg} /$ planted ha $)$ & 615 & 1,015 & 693 & 927 & 1,842 & 481 & 564 \\
\hline Consumption, 1995 & 19 & $8^{\mathrm{j}}$ & 36 & j & 10 & na & 5,920 \\
\hline
\end{tabular}


Sources: $\quad$ Barlow, Jayasuriya and Tan (1994); International Rubber Study Group, 1946-96.

Notes: $\quad$ a. Kampuchean and 'other' Southeast Asian production included in Viet Nam up to 1970.

b. Figures in parentheses along production lines are shares of each country's NR production in total world production.

c. Figures in brackets along this line are per cents of smallholdings in total planted area of early 1990s.

d. Probably about 30 per cent, with the balance being under state farms.

e. Estimated by author, using best available information.

f. But the smallholder area in particular is badly managed.

g. All African production included under 'Nigeria' up to 1990.

h. Mainly Brazil and Guatemala up to 1970. Subsequently including Myanmar, Liberia, Zaire and several other small producers.

i. Per cent of holdings less than 5 ha.

j. All African consumption included under Ivory Coast. 
Table 3. Economic circumstances of natural rubber producing countries ${ }^{a}, 1970$ s-1990s

\begin{tabular}{|c|c|c|c|c|c|c|}
\hline & Thailand & Indonesia & Malaysia & India & China & Sri Lanka \\
\hline Current GNP/head (\$), $1973(1993)^{\mathrm{bc}}$ & $\begin{array}{r}270 \\
(2,713)\end{array}$ & $120(969)$ & $\begin{array}{r}600 \\
(4,010)\end{array}$ & $130(331)$ & na (506) & $230(600)$ \\
\hline $\begin{array}{l}\text { GDP Growth (\%/year), 1973-83 (1984-93) } \\
\text { GDP Shares }{ }^{\mathrm{e}}(\%)\end{array}$ & $7.8(8.7)$ & $6.8(6.0)$ & $7.6(6.6)$ & $4.3(4.9)$ & $6.6(10.3)$ & $5.8(4.2)$ \\
\hline $\begin{array}{l}\text { 1973, Agriculture (Manufacturing) } \\
\text { - } \quad \text { 1993, Agriculture (Manufacturing) }\end{array}$ & $\begin{array}{l}23(20) \\
10(30)\end{array}$ & $\begin{array}{r}33(6) \\
17(25)\end{array}$ & $\begin{array}{l}29(16) \\
14(33)\end{array}$ & $\begin{array}{l}42(15) \\
29(19)\end{array}$ & $\begin{array}{l}44(24) \\
21(44)\end{array}$ & $\begin{array}{l}33(17) \\
23(19)\end{array}$ \\
\hline $\begin{array}{l}\text { Exchange Rate Change }^{\mathrm{d}} \\
-\quad 1973 \text { as \% } 1983 \text { (1983 as \% 1993) } \\
\text { Current Agric. Wage (\$ per day) } 1973 \\
(1996)^{\mathrm{e}}\end{array}$ & $\begin{array}{r}90(91) \\
1.08(5.50)\end{array}$ & $\begin{array}{r}45(44) \\
0.50(1.70)\end{array}$ & $\begin{array}{r}105(90) \\
2.70(8.50)\end{array}$ & $\begin{array}{r}76(33) \\
\operatorname{low}^{f}(1.70)\end{array}$ & $\begin{array}{r}76(33) \\
\operatorname{low}^{f} \\
(2.30)\end{array}$ & $\begin{array}{r}27(49) \\
\operatorname{low}^{f}(1.50)\end{array}$ \\
\hline & Viet Nam & Nigeria & $\begin{array}{l}\text { Ivory } \\
\text { Coast }\end{array}$ & $\begin{array}{l}\text { Philippine } \\
\text { s }\end{array}$ & Cameroon & World \\
\hline Current GNP/head (\$), $1973(1993)^{\mathrm{bc}}$ & na (219) & $310(300)$ & $350(630)$ & $\begin{array}{r}250 \\
(1,105)\end{array}$ & $220(820)$ & $\begin{array}{r}1,130 \\
(4,420)\end{array}$ \\
\hline $\begin{array}{l}\text { GDP Growth (\%/year), 1973-83 (1984-93) } \\
\text { GDP Shares }{ }^{\mathrm{e}}(\%)\end{array}$ & na (na) & $1.8(4.1)$ & $4.0(-0.3)$ & $5.2(1.1)$ & $9.2(-1.8)$ & $2.9(3.1)$ \\
\hline $\begin{array}{l}\text { - 1973, Agriculture (Manufacturing) } \\
\text { - } \quad \text { 1993, Agriculture (Manufacturing) }\end{array}$ & $\begin{array}{l}\text { na (na) } \\
27(23)\end{array}$ & $\begin{array}{l}44(5) \\
33(9)\end{array}$ & $\begin{array}{l}48 \text { (na) } \\
37 \text { (na) }\end{array}$ & $\begin{array}{l}27(29) \\
21(26)\end{array}$ & $\begin{array}{r}41(5) \\
25(12)\end{array}$ & $\begin{array}{l}\text { na (na) } \\
\text { na (na) }\end{array}$ \\
\hline $\begin{array}{l}\text { Exchange Rate Change } \\
-\quad 1973 \text { as \% } 1983 \text { (1983 as \% 1993) } \\
\text { Current Agric. Wage (\$ per day), } 1973 \\
(1996)^{\mathrm{e}}\end{array}$ & $\begin{array}{l}\text { na }(\text { neg) } \\
\text { na }(\text { low })^{f}\end{array}$ & $\begin{array}{r}91(3) \\
\text { na (low) }\end{array}$ & $\begin{array}{r}58(135) \\
\operatorname{low}^{f}(2.80)\end{array}$ & $\begin{array}{c}61(41) \\
\operatorname{low}^{f}(2.30)\end{array}$ & $\begin{array}{r}68(134) \\
\operatorname{low}^{f} \\
(2.00)\end{array}$ & $\begin{array}{c}-(-) \\
\operatorname{na}(\text { na) }\end{array}$ \\
\hline
\end{tabular}

Sources: World Tables (1996).

Notes: $\quad$ a. Excluding Kampuchea, for which no data is available.

b. Figures for Thailand, Indonesia, Malaysia, India, China, Viet Nam and the Philippines refer to 1995.

c. Items in parentheses match with subsequent figures in parentheses in each case.

d. Rate of local currency against US\$ in first year as a per cent of rate in second year. Per cents below 100 imply depreciation, and above 100 appreciation, of currency concerned.

e. Estimated on basis of available information. Rates include value of perquisites and apply to major rubber-growing areas of countries.

f. Below $\$ 1.00$ per day. 
Table 4. Estimated revenues and costs from smallholder natural rubber production in advancing economies

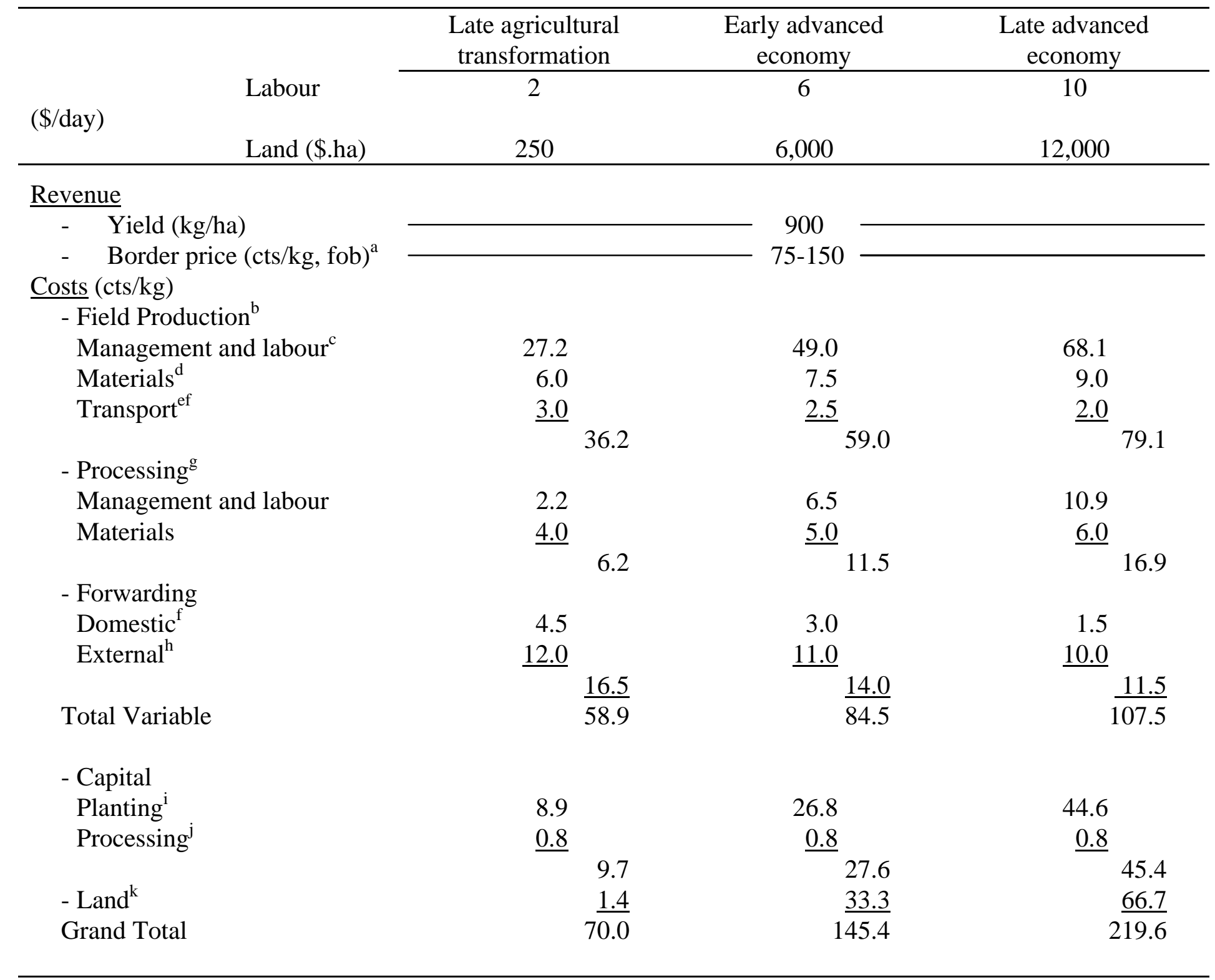

Notes: $\quad$ a. For Technically Specified Rubber (TSR) as the major internationally marketed grade.

b. Including initial processing to low-level intermediate goods (sheet or slab).

c. Taking task sizes of 300 trees per tapper (late agricultural transformation), 500 trees (early advanced economy) and 600 trees (late advanced economy), with common densities of 350 tapped trees per ha and tapping days of 105 per year.

d. Including costs of equipment.

e. To point of high-level intermediate processing. This cost is usually incurred by traders.

f. Assuming progressive falls in domestic transportation costs with better roads in advancing economies.

g. Into high-level intermediate product.

h. From national boundaries to rubber goods factories in foreign industrial centres. Assuming some decline in external forwarding costs with better port facilities in advancing economies.

i. Principal repayment and 5 per cent real interest charges over 20 years on gross investments in bringing plantings to maturity of $\$ 1,000 /$ ha (late agricultural transformation with $\$ 2 /$ day labour cost), $\$ 3,000 /$ ha (early advanced economy with $\$ 6 /$ day labour cost) and $\$ 5,000 /$ ha (late advanced economy with $\$ 10 /$ day labour cost).

j. Principal repayment and 5 per cent real interest charges over 20 years on investments in all cases of $\$ 1.2$ million for a $60 t /$ day TSR factory with 75 per cent capacity utilization. 
k. 5 per cent real interest charges on land costs shown. 
Table 5. Mean factor prices and factor use in initial development and field production of natural rubber, Malaysian estates and smallholdings, 1922-1995.

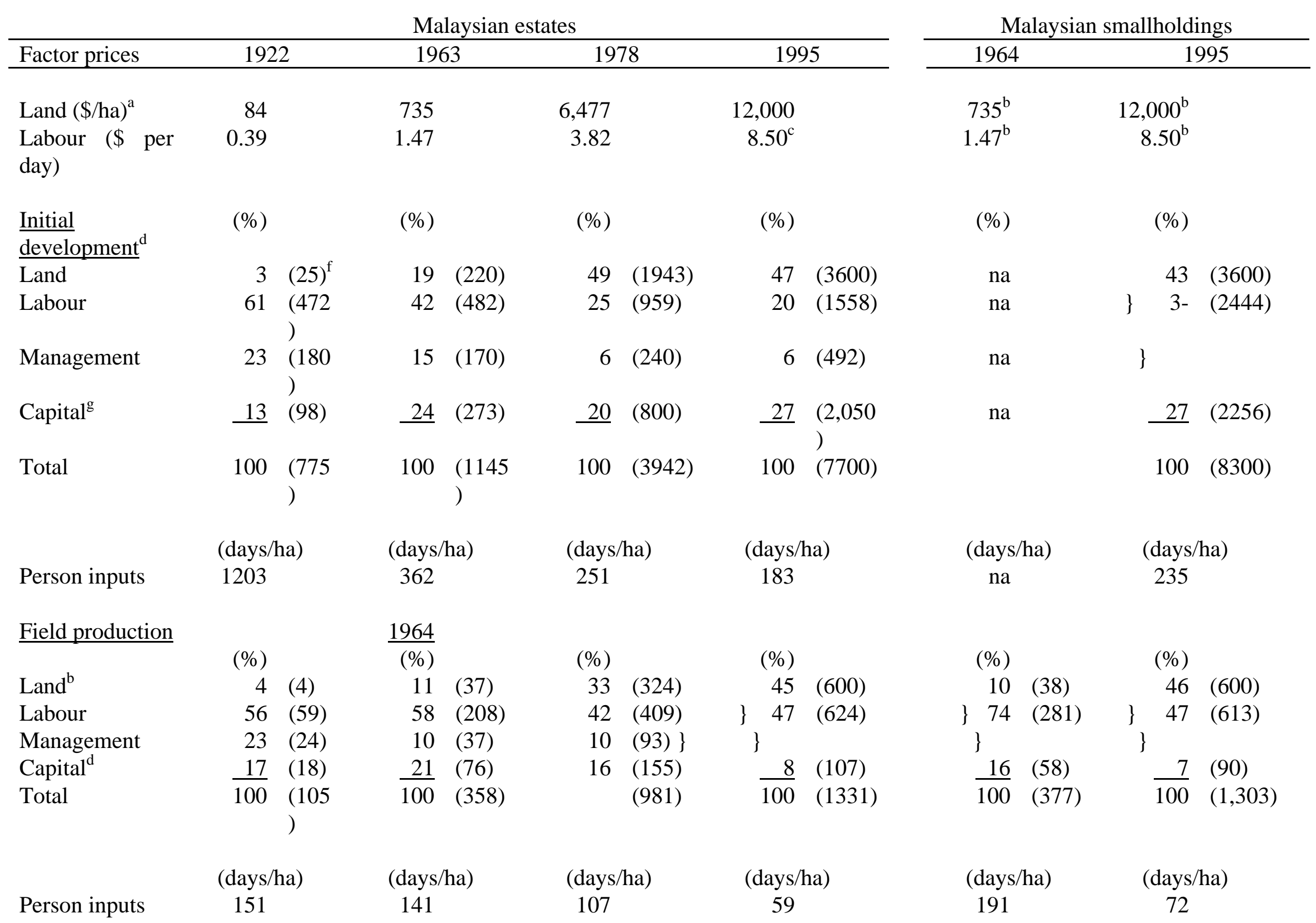


Sources: Large sample surveys of estate companies and smallholdings by agencies and the author in countries concerned. Sources are given by Barlow, Tan and Jayasuriya (1994).

Notes: a. Land prices are averages of ranges quoted in surveys for years shown.

b. Actual opportunity costs of smallholding land and labour were frequently lower.

c. Wage for local Malaysian labour. Migrant labour was often cheaper.

d. Initial development by clearing, planting and maintenance to maturity (and tapping commencement) over a 6 year gestation period.

e. Land costs are estimated as 5\% interest on current values over the 6 year gestation period.

f. Figures in parentheses are nominal costs in \$ per hectare (at concurrent \$US exchange rates with ringgits in which costs originally quoted).

g. All purchased inputs other than labour and management, and including working capital. 